\title{
A low-cost lead-acid battery with high specific-energy
}

\author{
S K MARTHA, ${ }^{1}$ B HARIPRAKASH,${ }^{1}$ S A GAFFOOR, ${ }^{2}$ D C TRIVEDI ${ }^{3}$ and A K SHUKLA ${ }^{1,3, *}$ \\ ${ }^{1}$ Solid State and Structural Chemistry Unit, Indian Institute of Science, Bangalore 560012 \\ ${ }^{2}$ NED Energy Ltd, 6-3-1109/1 Navbharat Chambers, Raj Bhavan Road, Hyderabad 560082 \\ ${ }^{3}$ Central Electrochemical Research Institute, Karaikudi 630006 \\ e-mail: shukla@sscu.iisc.ernet.in
}

\begin{abstract}
Lightweight grids for lead-acid battery grids have been prepared from acrylonitrile butadiene styrene (ABS) copolymer followed by coating with lead. Subsequently, the grids have been electrochemically coated with a conductive and corrosion-resistant layer of polyaniline. These grids are about $75 \%$ lighter than those employed in conventional lead-acid batteries. Commercial-grade $6 \mathrm{~V} / 3 \cdot 5 \mathrm{Ah}\left(\mathrm{C}_{20}\right.$-rate $)$ lead-acid batteries have been assembled and characterized employing positive and negative plates constituting these grids. The specific energy of such a lead-acid battery is about $50 \mathrm{Wh} / \mathrm{kg}$. The batteries can withstand fast charge-discharge duty cycles.
\end{abstract}

Keywords. Lead-acid battery; specific energy; polyaniline; corrosion.

\section{Introduction}

Research and development efforts are currently under way to enhance the specific energy of lead-acid batteries, which at present remains restricted to only about $30 \mathrm{Wh} / \mathrm{kg}$ owing to the high mass-density of lead. In the literature, Hammar et $a l^{1}$ have reported a lead-acid battery in which the grids comprise a substrate made of a polymer, such as polyvinyl chloride, laminated with a thin lead/lead alloy foil. This combination reduces the weight of the battery grid, contributing to an increase in the specific energy of the battery. However, Hammar et al do not appear to apply a corrosion-resistant coating on the substrate. As a result, the grids become susceptible to corrosion in acid medium, thereby limiting the durability of the batteries. Pinsky et $a l^{2}$ have reported a positive grid coated with electrically conductive-doped tin oxide for lead-acid batteries. Rowlette ${ }^{3}$ has reported battery grids made of metallic substrates like aluminum or titanium or their alloys coated with lead/lead alloy. These metallic substrates still have unacceptably high mass-density. Accordingly, it is desirable to produce grids using substrates made of materials having a even lower mass densities. Tsuchida et $a l^{4}$ employed polyamide and glass fibres to construct the lead-acid battery grids. The weight of the grid is reduced, in comparison with conventional grid

Dedicated to Prof J Gopalakrishnan on his 62nd birthday

*For correspondence made entirely of lead/lead alloys, by using low-density polyamide to form a support structure, and a glass fibre sheet coated by a thin layer of lead/lead alloy to form the electricity-collecting part of the battery grid. However, a corrosion-resistant coating appears to be absent even on these grids, which makes the grids prone to acid corrosion. Timmons et al describe another approach to reduce the weight of lead-acid batteries with its plate made of non-lead substrates such as aluminum encapsulated by thin sheets of conductive foils of lead/lead alloy; this approach also suffers from inadequacies similar to those described earlier.

Recently, Kurisawa et $a l^{6}$ have attempted to use the radio-frequency sputtering technique to form protective tin oxide coating on lead grids. However, sputtering is generally a slow process, and since it happens to be a line-of-sight process, both sides of the grids cannot be coated simultaneously, unless a complex and expensive sputtering apparatus is employed. Accordingly, the cost of forming a corrosion-resistant coating on the grids by a sputtering process is likely to be high. Similar studies to develop high specific energy leadacid batteries have also been reported. ${ }^{7-12}$ More recently, Shivashankar et $a l^{13,14}$ have employed a costeffective, thermally activated chemical reaction process to produce tin oxide-coated plastic grids for lead-acid batteries. Ironically, however, positive plates constituting tin oxide coated grids have been found to be unstable in lead-acid batteries at $0.5 \mathrm{~V}$ vs $\mathrm{Pb} / \mathrm{PbSO}_{4}$ electrode. ${ }^{13,14}$ Accordingly, it is desirable to find a room temperature process, to provide a corrosion- 
resistant coating on battery grids constituted from lightweight and inexpensive plastic materials, usually having a low-melting point.

In this study, we have employed a novel room-temperature process ${ }^{15}$ to corrosion protect the lightweight lead-acid battery grids coated with a lead metal layer by electrodepositing polyaniline (PANI). Using these grids it has been possible to produce $6 \mathrm{~V} / 3.5 \mathrm{Ah}$ $\left(\mathrm{C}_{20}\right.$-rate $)$ lead-acid batteries with specific energies of about $50 \mathrm{Wh} / \mathrm{kg}$. The batteries can withstand fast charge-discharge duty cycles. Accordingly, the study opens up a new realm of possibilities for lead-acid battery development.

\section{Experimental}

\subsection{Preparation and corrosion protection of grids}

Battery grids of dimension $6.5 \times 2.8 \times 0.2 \mathrm{~cm}$ were injection-moulded from AP78EP grade ABS rubber. The grids were then coated with copper metal layer of $10 \mu \mathrm{m}$. This was followed by a lead metal coating of $100 \mu \mathrm{m}$. The grids were subsequently corrosionprotected with about $1 \mu \mathrm{m}$ of PANI layer as described below.

The lead-coated grids were placed in a bath containing $1 \mathrm{v} / \mathrm{o}$ aqueous solution of aniline in $0.3 \mathrm{~N}$ oxalic acid with each of the grids held between two symmetrically placed dimensionally stable platinumcoated titanium electrodes. A thin layer of PANI was subsequently electrodeposited on to the battery grids by applying an electric potential of $1.4 \mathrm{~V}$ across the grids and the counter electrodes. ${ }^{16}$ The grids were finally washed copiously with de-ionized water and dried in a hot air oven at about $65^{\circ} \mathrm{C}$. The deposition of PANI films on the grids was confirmed by cyclic voltammetry. The grids were carefully cut using a diamond-wheel and the cross sectional view of various layers deposited on the ABS grid was obtained using a JEOL JSM 840A scanning electron microscope.

\subsection{Assembly of AGM-VRLA batteries}

6V/3.5Ah $\left(\mathrm{C}_{20}\right.$-rate $)$ AGM-VRLA batteries were assembled by series stacking two positive and three negative plates in each cell, and inter-cell connections were made by group burning. Positive and negative plates in the cells were separated by placing $2 \mathrm{~mm}$ thick AGM separator obtained from Nippon Sheet Glass Co., Japan. The cells were filled with the required amount of $4.5 \mathrm{M}$ aqueous sulphuric acid and were kept for about $2 \mathrm{~h}$ to facilitate electrolyte soaking. The batteries were made positive limited to facilitate oxygen recombination at the negative plates.

\subsection{Formation and testing of AGM-VRLA batteries}

The batteries were formed over 3 cycles by charging them galvanostatically at $\mathrm{C} / 10$ rate followed by their discharge at $\mathrm{C} / 5$ rate using Keithley voltage/current source interfaced to a data acquisition system. The batteries were subjected to various charge/discharge studies at varying rates at temperatures ranging between -20 and $50^{\circ} \mathrm{C}$ in a temperature-controlled chamber.

\subsection{Grid corrosion studies}

Grid corrosion studies on the grids were conducted by obtaining the cyclic voltammograms in the potential range between 0.6 and $1.56 \mathrm{~V}$ vs $\mathrm{Hg} / \mathrm{Hg}_{2} \mathrm{SO}_{4}, \mathrm{SO}_{4}^{2-}$ (MMS) reference electrode at a scan rate of $20 \mathrm{mVs}^{-1}$ using an Autolab (PGSTAT-30). Industrial, gridcorrosion experiments on the battery grids were also performed in a cell comprising a positive grid placed between two negative plates immersed in $\mathrm{H}_{2} \mathrm{SO}_{4}$ electrolyte maintained at $55^{\circ} \mathrm{C}$. The grids were held potentiostatically at $2.5 \mathrm{~V}$ for 7 days and the variations in the current were recorded continuously. Subsequently, the grids were removed and washed copiously with the de-ionized water. The corrosion layer on the positive grid was stripped by dipping it in aqueous red-lead extraction solution comprising sodium acetate trihydrate, potassium iodide and glacial acetic acid. The grids were finally washed copiously with de-ionized water and dried in a hot air oven at about $60^{\circ} \mathrm{C}$. The corrosion rate was determined from the weight loss of the grids.

\subsection{Cycle-life studies on 6 V/3.5 Ah AGM-VRLA batteries}

Cycle-life data on $6 \mathrm{~V} / 3.5$ Ah $\left(\mathrm{C}_{20}\right.$-rate $)$ lead-acid batteries were also obtained at $\mathrm{C} / 5$ rate and $25^{\circ} \mathrm{C}$ employing a Keithley voltage/current source interfaced to a data acquisition system.

\section{Results and discussion}

Figure 1a shows the cross-sectional scanning electron micrograph (SEM) of the grid. We clearly see the respective layers of $\mathrm{ABS}, \mathrm{Cu}, \mathrm{Pb}$, and PANI. The 
micrograph shows a copper layer of about $10 \mu \mathrm{m}$, lead layer of about $100 \mu \mathrm{m}$, and PANI layer of about $1 \mu \mathrm{m}$ thicknesses respectively. The micrograph of the PANI film shown in figure $1 \mathrm{~b}$ suggests PANI particles of size ranging between 1 and $2 \mu \mathrm{m}$. The growth pattern of the PANI film on a $0.25 \mathrm{~cm}^{2}$ area lead sheet is depicted in figure 2. It is noteworthy that the film growth in oxalic acid is quite different from that in sulphuric acid owing to the reducing nature of the former. Nevertheless, PANI obtained in oxalic aid has characteristically similar cyclic voltammogram as in sulphuric acid ${ }^{16}$ (figure 3 ). In the cyclic voltammogram, peak I refers to leucoemaraldine (LE) $\rightarrow$ emeraldine (EM), peak II refers to EM $\rightarrow$ pernigraniline $(\mathrm{PE})$, peak III refers to $\mathrm{PE} \rightarrow \mathrm{EM}$, and peak IV refers to $\mathrm{EM} \rightarrow \mathrm{LE}$.

The cyclic voltammograms of $\mathrm{ABS} / \mathrm{Cu} / \mathrm{Pb}$ and $\mathrm{ABS} / \mathrm{Cu} / \mathrm{Pb} / \mathrm{PANI}$ grids in the potential range between 0.6 and $1.56 \mathrm{~V}$ vs MMS electrode are shown in figure 4. The cyclic voltammetry data for the $\mathrm{ABS} / \mathrm{Cu} / \mathrm{Pb}$ grid show distinct peak currents at $1.1 \mathrm{~V}$ vs MMS electrode due to the oxidation of $\mathrm{PbSO}_{4}$ to $\mathrm{PbO}_{2}$, and
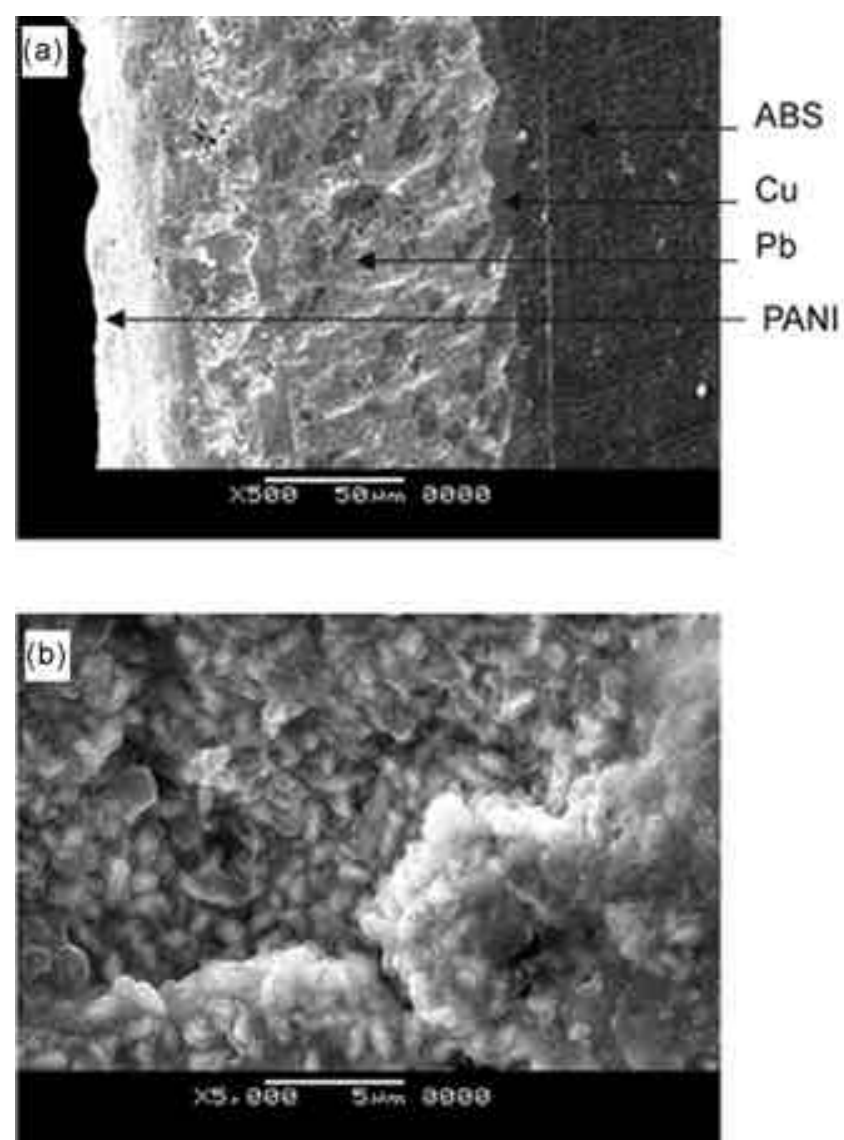

Figure 1. Electron micrographs depicting (a) crosssectional, and (b) surface morphologies of $\mathrm{ABS} / \mathrm{Cu} / \mathrm{Pb} /$ PANI grids. at $0.95 \mathrm{~V}$ vs MMS electrode arising from the reduction of $\mathrm{PbO}_{2}$ to $\mathrm{PbSO}_{4}$. In contrast, we observe nearly complete suppression of these peaks in the cyclic voltammogram for the $\mathrm{ABS} / \mathrm{Cu} / \mathrm{Pb} / \mathrm{PANI}$ grids, suggesting substantial mitigation of lead corrosion from the grids. It appears that the conversion of $\mathrm{PbO}_{2}$ to $\mathrm{PbSO}_{4}$ and vice versa is suppressed due to the doping reaction of PANI with sulphuric acid resulting in a compact barrier layer as shown in Figure 1a.

Potentiostatic corrosion data obtained on the positive grids are shown in figure 5 . The data show lower corrosion rate for the $\mathrm{ABS} / \mathrm{Cu} / \mathrm{Pb} / \mathrm{PANI}$ grids in re-

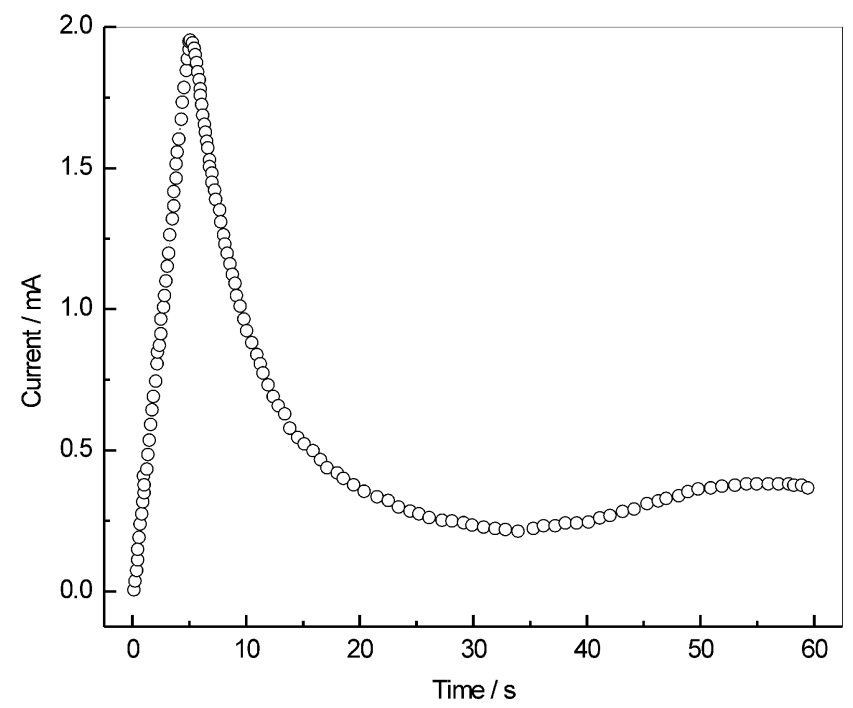

Figure 2. Current vs time response during PANI film formation at $1.4 \mathrm{~V}$ on a $0.25 \mathrm{~cm}^{2}$ lead sheet in presence of oxalic acid by potential-step technique.

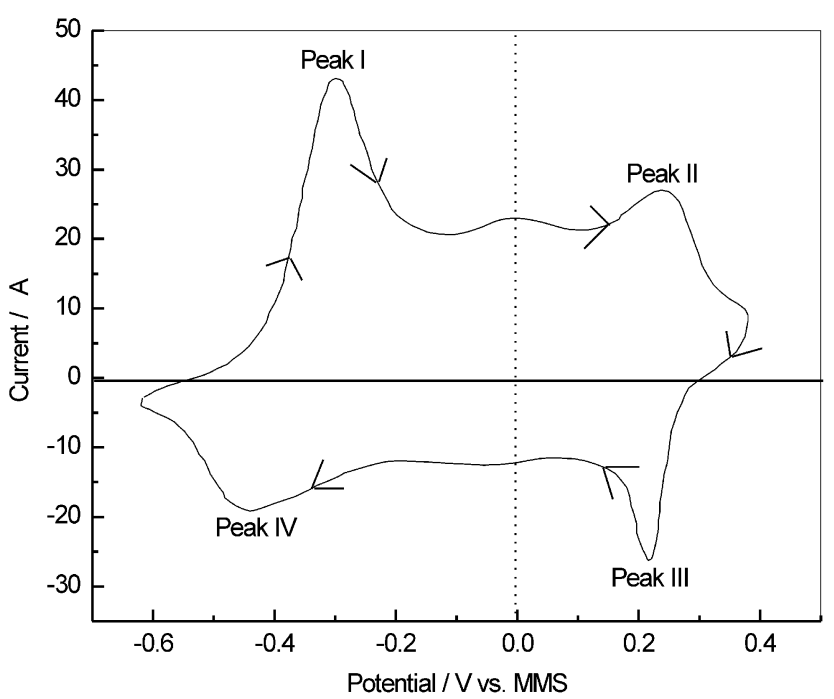

Figure 3. Cyclic voltammogram of PANI deposited on a $0.25 \mathrm{~cm}^{2}$ lead sheet in $1 \mathrm{M} \mathrm{H}_{2} \mathrm{SO}_{4}$ at a scan rate of $50 \mathrm{mV} \mathrm{s}^{-1}$. 
lation to the uncoated $\mathrm{ABS} / \mathrm{Cu} / \mathrm{Pb}$ grids, which is in accordance with cyclic voltammogram data shown in figure 4 . The corrosion rates obtained from the weight loss method for $\mathrm{ABS} / \mathrm{Cu} / \mathrm{Pb} / \mathrm{PANI}$ and $\mathrm{ABS} /$ $\mathrm{Cu} / \mathrm{Pb}$ grids are found to be $2 \times 10^{-3}$ and $22 \times 10^{-3} \mathrm{~g} /$ $\mathrm{cm}^{2} /$ day, respectively. After confirming the stability of the $\mathrm{ABS} / \mathrm{Cu} / \mathrm{Pb} / \mathrm{PANI}$ grids in aq. $\mathrm{H}_{2} \mathrm{SO}_{4}$, the grids were pasted with active material to form $6 \mathrm{~V} / 3.5$ Ah lead-acid batteries. The ohmic-drop experiments conducted on $\mathrm{ABS} / \mathrm{Cu} / \mathrm{Pb} / \mathrm{PANI}$ and $\mathrm{ABS} / \mathrm{Cu} / \mathrm{Pb}$ grids yield comparative values between $10-15 \mathrm{~m} \Omega$, suggesting the $\mathrm{ABS} / \mathrm{Cu} / \mathrm{Pb} / \mathrm{PANI}$ grids to be appropriate for usage in lead-acid cells/batteries.

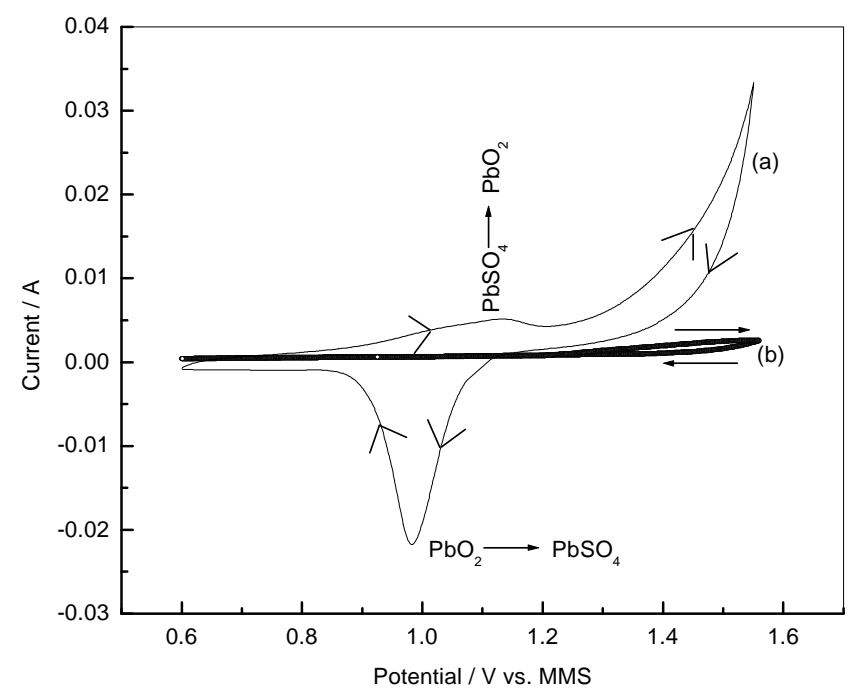

Figure 4. Comparative cyclic voltammograms for (a) $\mathrm{ABS} / \mathrm{Cu} / \mathrm{Pb}$, and (b) $\mathrm{ABS} / \mathrm{Cu} / \mathrm{Pb} / \mathrm{PANI}$ grids.

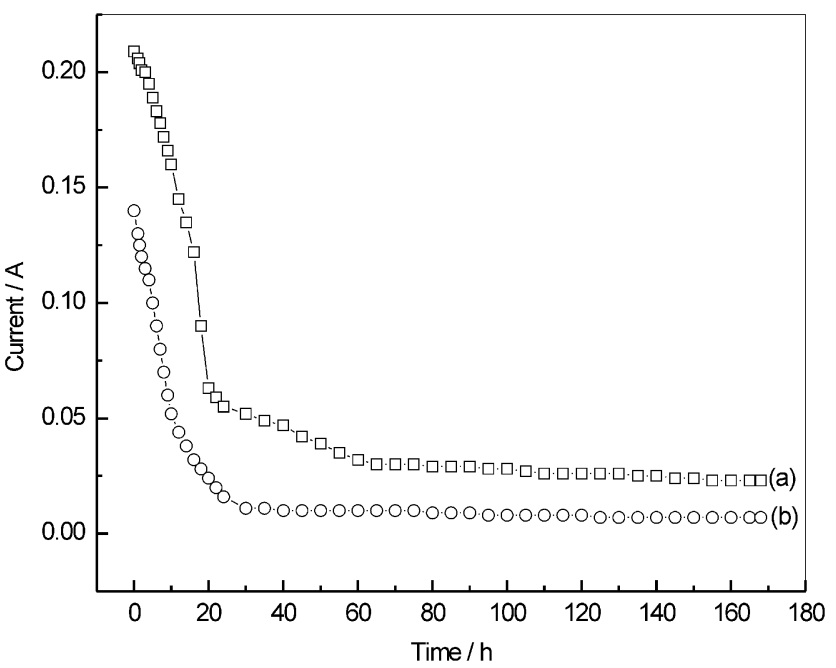

Figure 5. Comparative potentiostatic corrosion data for (a) $\mathrm{ABS} / \mathrm{Cu} / \mathrm{Pb}$, and (b) $\mathrm{ABS} / \mathrm{Cu} / \mathrm{Pb} / \mathrm{PANI}$ positive grids at a charging voltage of $2.5 \mathrm{~V}$ at $55^{\circ} \mathrm{C}$.
$6 \mathrm{~V} / 3.5$ Ah batteries assembled by connecting the three $2 \mathrm{~V} / 3.5$ Ah cells in series were subjected to formation cycles, and typical $5 \mathrm{~h}$-rate $(\mathrm{C} / 5)$ galvanostatic charge-discharge data for the battery obtained at $25^{\circ} \mathrm{C}$ are shown in figure 6 . The data suggest faradaic efficiency of about $92 \%$ for the battery. Performance characteristics of the battery at different rates ranging between $\mathrm{C} / 20$ and $3 \mathrm{C}$ rates are shown in figure 7. As expected, the batteries exhibit a capacity

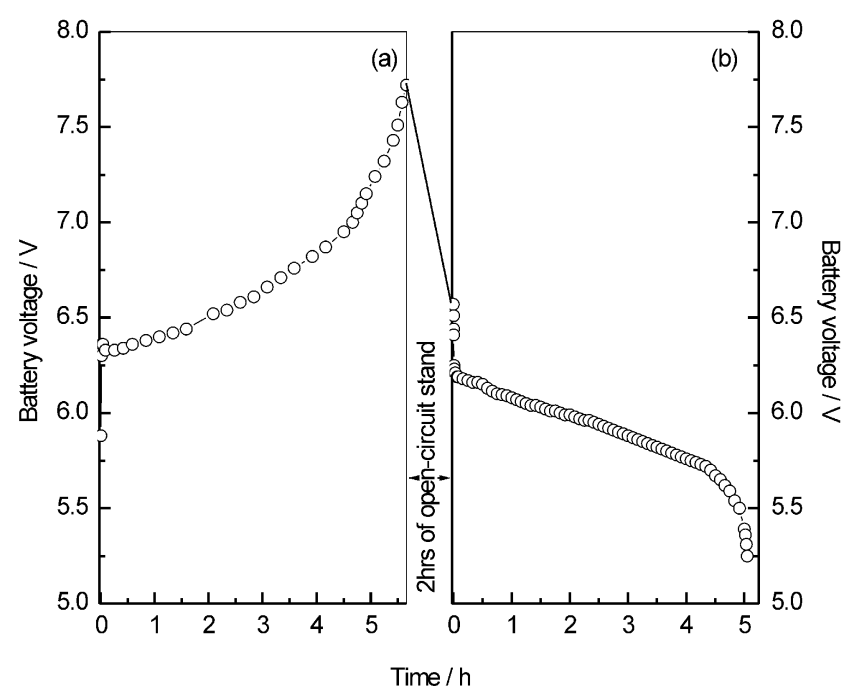

Figure 6. A typical $\mathrm{C} / 5$ rate galvanostatic chargedischarge data for a $6 \mathrm{~V} / 3.5 \mathrm{Ah}$ lead-acid battery with lightweight modified grids obtained at $25^{\circ} \mathrm{C}$.

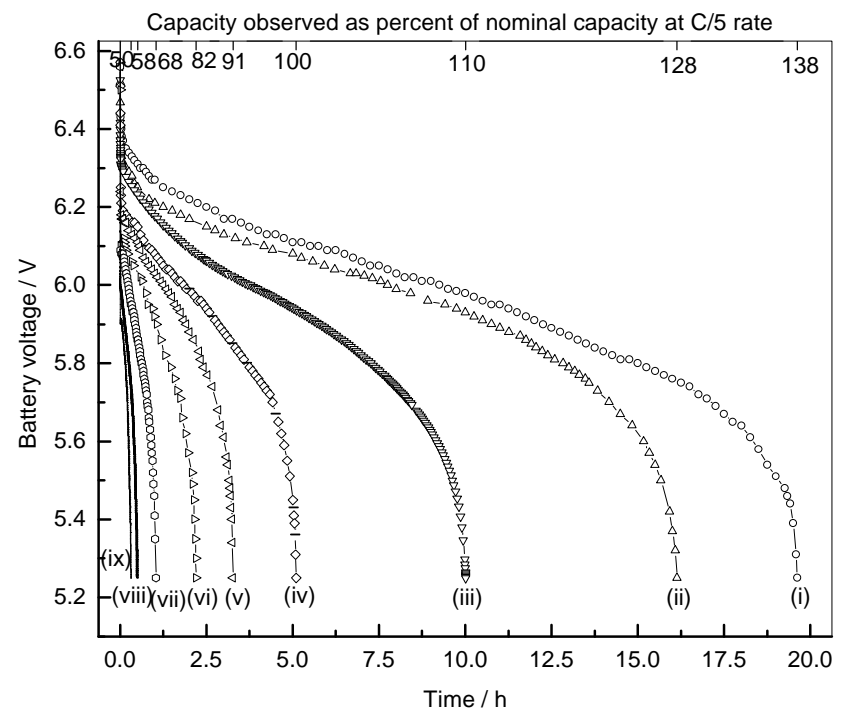

Figure 7. Performance characteristics of a $6 \mathrm{~V} / 3.5 \mathrm{Ah}$ lead-acid battery with lightweight modified grids obtained at $25^{\circ} \mathrm{C}$ for (i) $\mathrm{C} / 20$, (ii) $\mathrm{C} / 15$, (iii) $\mathrm{C} / 10$, (iv) $\mathrm{C} / 5$, (v) $\mathrm{C} / 3$, (vi) $\mathrm{C} / 2$, (vii) $\mathrm{C}$, (viii) $2 \mathrm{C}$, and (ix) $3 \mathrm{C}$ discharge rates. 
increase of about $35 \%$ at $\mathrm{C} / 20$ rate as compared to its capacity at $\mathrm{C} / 5$ rate; the batteries also perform better at higher discharge rates between $2 \mathrm{C}$ and $3 \mathrm{C}$. Figure 8 shows the discharge data at different temperatures between 50 and $-20^{\circ} \mathrm{C}$. As seen from the data in figure 8 , the batteries exhibit a $24 \%$ increase in capacity at $50^{\circ} \mathrm{C}$ in relation to the value observed at $25^{\circ} \mathrm{C}$. At temperatures below $25^{\circ} \mathrm{C}$, the capacity values of the battery were found to decrease with temperature.

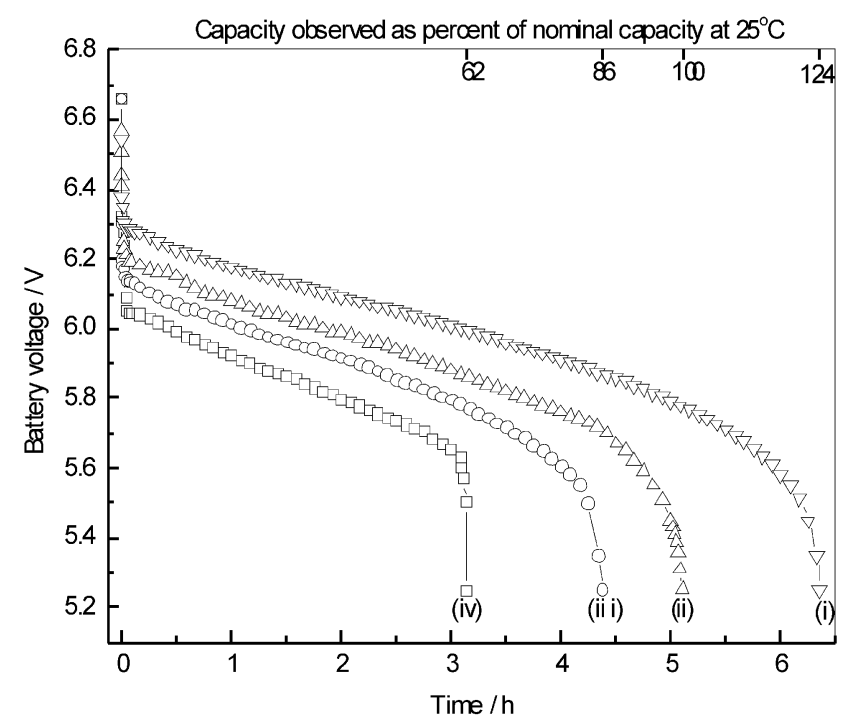

Figure 8. Effect of temperature on the discharge capacities of a $6 \mathrm{~V} / 3.5 \mathrm{Ah}$ lead-acid battery with lightweight modified grids obtained for $\mathrm{C} / 5$ rate at (i) $50^{\circ} \mathrm{C}$, (ii) $25^{\circ} \mathrm{C}$, (iii) $0^{\circ} \mathrm{C}$, and (iv) $-20^{\circ} \mathrm{C}$.

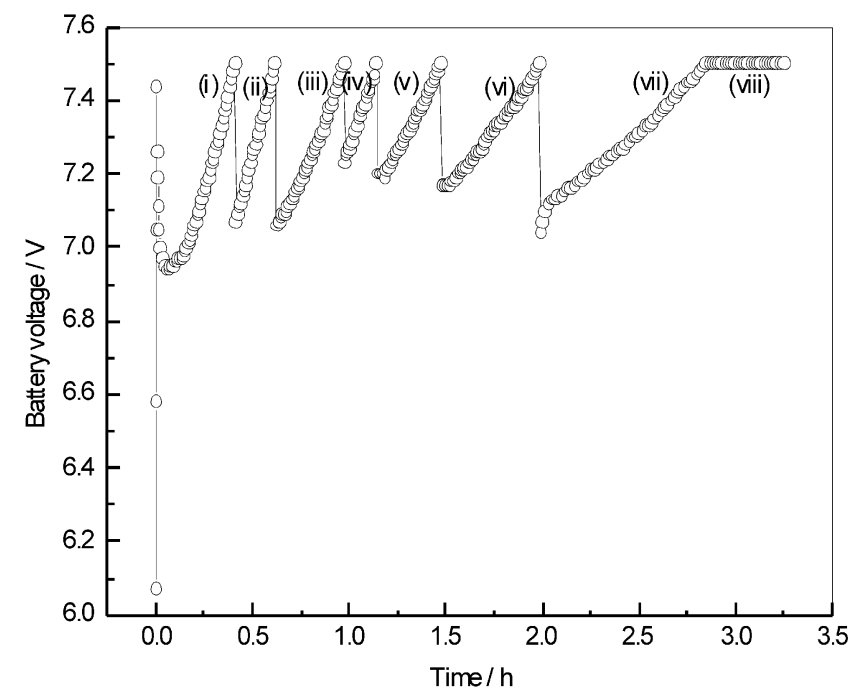

Figure 9. High-rate charging data for a $6 \mathrm{~V} / 3 \cdot 5 \mathrm{Ah}$ leadacid battery with lightweight modified grids obtained at $25^{\circ} \mathrm{C}$ during (i) $2 \mathrm{C}$, (ii) $\mathrm{C}$, (iii) $\mathrm{C} / 2$, (iv) $\mathrm{C} / 3$, (v) $\mathrm{C} / 5$, (vi) $\mathrm{C} / 10$, and (vii) $\mathrm{C} / 20$, and (viii) constant potential charging.
In order to check the high-rate charge characteristics and deep-discharge recovery of the batteries, they were charged at varying rates over a total period of $3 \mathrm{~h}$ as shown in figure 9 . The data suggest a charge acceptance of $90 \%$ within $1.5 \mathrm{~h}$ of charge and a full charge acceptance within $3 \mathrm{~h}$. The batteries were discharged at $\mathrm{C} / 5$ rate soon after the charging as shown in figure 10a. It is also found that the discharge capacity of the batteries subsequent to the aforesaid charging is

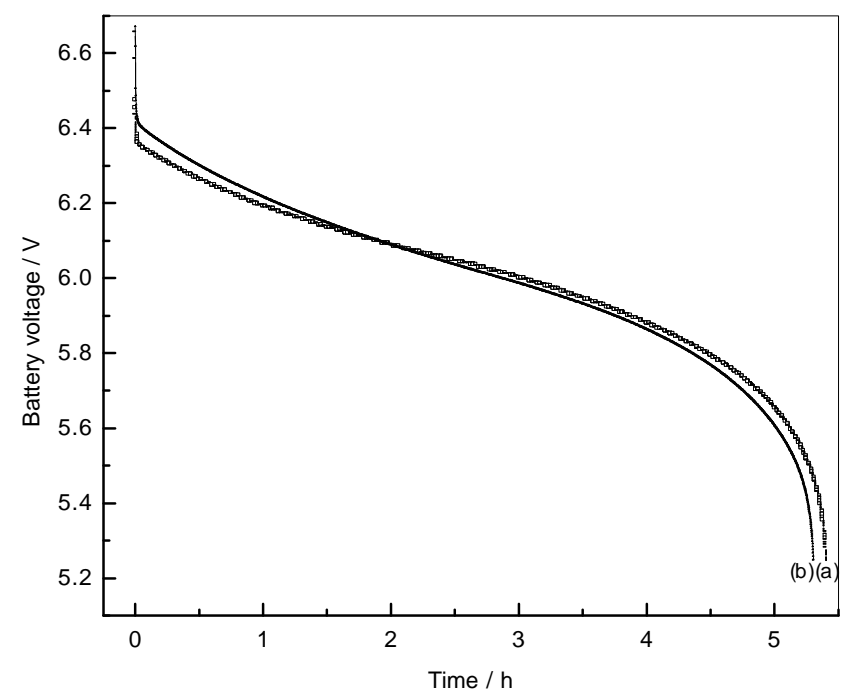

Figure 10. Discharge data obtained at $25^{\circ} \mathrm{C}$ at $\mathrm{C} / 5$ rate for a $6 \mathrm{~V} / 3.5 \mathrm{Ah}$ lead-acid battery with lightweight modified grids after charging as per schedule shown in figure 9: (a) before storage, and (b) after storage for five days in discharge state.

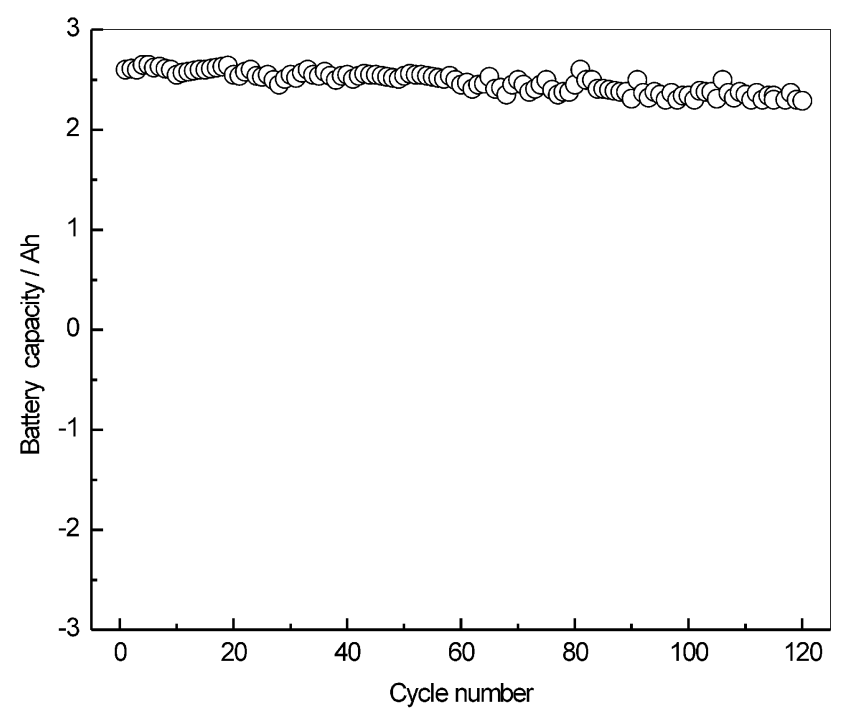

Figure 11. Cycle-life data for a $6 \mathrm{~V} / 3.5$ Ah lead-acid battery with lightweight modified grids obtained at $\mathrm{C} / 5$ rate at $25^{\circ} \mathrm{C}$. 
nearly similar to the capacity delivered after conventional galvanostatic charging at $\mathrm{C} / 5$ rate (see figure 6a). After their discharge, the batteries were kept standing for five days and again charged according to the schedule shown in figure 9. Subsequently, the batteries were discharged at $\mathrm{C} / 5$ rate as shown in figure 10b. A comparison of data in figures $10 \mathrm{a}$ and $b$ shows little difference in the charge acceptance of the batteries, suggesting that they are amenable both to high-rate charge and deep-discharge recovery. The batteries were successfully charged and discharged at $\mathrm{C} / 5$ rate at $25^{\circ} \mathrm{C}$ for 120 cycles with little change in capacity as shown in figure 11 .

\section{Conclusions}

Using a novel route to electrodeposit corrosion-resistant polyaniline layers onto the lead-coated lightweight plastic grids, lead-acid batteries with a specific energy value close to $50 \mathrm{Wh} / \mathrm{kg}$ have been realized. The batteries meet service requirements for fast charge-discharge duty cycles. Accordingly, this study is a major step forward in realizing a low-cost lead-acid battery with high specific energy.

\section{Acknowledgements}

We thank N Gautam, NED Energy Ltd, Hyderabad for his kind encouragement.

\section{References}

1. Hammer R H and Harvey D J 1980 US Patent $4,221,854$

2. Pinsky N and Alkaitis S A 1987 US Patent 4,713,306

3. Rowlette J J 1997 US Patent 5,643,696

4. Tsuchida K and Imai H 2001 US Patent 6,232,017

5. Timmons $\mathrm{J} \mathrm{B}$, Bhardwaj $\mathrm{R}$ and Orsino $\mathrm{J}$ A 2001 US Patent 6,316,148

6. Kurisawa I, Shiomi M, Ohsumi S, Iwata M and Tsubota M 2001 J. Power Sources 95125

7. Timmons J B, Orsino J A and Bhardwaj R 2002 US Patent 6,447,954

8. Bhardwaj R C and Than J 2000 J. Power Sources 91 51

9. Barkleit G, Grahl A, Maccangi M, Olper M, Scharf P, Wagner R and Warlimont H 1999 J. Power Sources 7873

10. Moseley P T and Prengaman R D 2002 J. Power Sources 107240

11. Wang J, Liu H K, Dou S X, Zhong S, Zhu Y and Fu C 2003 J. Power Sources 113241

12. Battlebury D R 1999 J. Power Sources 807

13. Shivashankar S A, Shukla A K, Mane A U, Hariprakash B and Gaffoor S A 2004 US Patent 0151982 A1

14. Hariprakash B, Mane A U, Martha S K, Gaffoor S A, Shivashankar S A and Shukla A K 2004 Electrochem. Solid-State Lett. 7 A66

15. Shukla A K, Martha S K, Hariprakash B, Gaffoor S A and Trivedi D C 2004 US Patent (filed)

16. Trivedi D C 1997 In Handbook of organic conducting molecules and polymers (New York: John Wiley) Ch. 12 